\title{
Evaluation of the Influence Caused by Tunnel Construction on Groundwater Environment: A Case Study of Tongluoshan Tunnel, China
}

\author{
Jian Liu, Dan Liu, and Kai Song \\ Faculty of Geosciences and Environmental Engineering, Southwest Jiaotong University, Chengdu, Sichuan 610031, China \\ Correspondence should be addressed to Jian Liu; liukai-102@163.com
}

Received 2 March 2015; Revised 10 June 2015; Accepted 11 June 2015

Academic Editor: João M. P. Q. Delgado

Copyright (c) 2015 Jian Liu et al. This is an open access article distributed under the Creative Commons Attribution License, which permits unrestricted use, distribution, and reproduction in any medium, provided the original work is properly cited.

Problems related to water inflow during tunnel construction are challenging to designers, workers, and management departments, as they can threaten tunneling project from safety, time, and economic aspects. Identifying the impacts on groundwater environment resulting from tunnel drainage and making a correct assessment before tunnel construction is essential to better understand troubles that would be encountered during tunnel excavation and helpful to adopt appropriate countermeasures to minimize the influences. This study presents an indicator system and quantifies each indicator of Tongluoshan tunnel, which is located in southwest China with a length of $5.2 \mathrm{~km}$ and mainly passes through carbonate rocks and sandstones, based on field investigation and related technological reports. Then, an evaluation is made using fuzzy comprehensive assessment method, with a result showing that it had influenced the local groundwater environment at a moderate degree. Information fed back from environmental investigation and hydrologic monitoring carried out during the main construction period proves the evaluation, as the flow of some springs and streams located beside the tunnel route was found experiencing an apparent decline.

\section{Introduction}

Nowadays, more and more tunnels are constructed for the reason that efficient transport strongly relies on road and railway tunnel, both in long-distance traffic and in metropolitan areas $[1,2]$. However, when a tunnel interferes with groundwater in complex geological media, especially in carbonate karstic rocks, serious problems can arise during the excavation because of groundwater inflow, which is known as one of the most common but challenging problems faced by tunnel designers and constructors, leading to unsafe conditions, high construction costs, and delays, not to mention the risk to life and damage to property $[1,3-7]$. Yuanliangshan tunnel on Chongqing-Huaihua railway in China came across three large filled caves at Maoba syncline carbonate strata, and a volume of approximately $4200 \mathrm{~m}^{3}$ of clay erupted within 30 seconds in one cave of them, causing casualties and severe damage to the equipment in tunnel [8]. During the construction of Pinglin tunnel in Taiwan, the major difficulties encountered are caused by sudden high-pressure groundwater inflow, with a yield of approximately $180 \mathrm{~L} / \mathrm{s}$ in the pilot tunnel as an example, leading to the TBM being trapped and damaged and construction progress being greatly impacted [9]. Due to fluid drainage and pore pressure changes following tunnel construction, vertical settlements with magnitudes reaching $12 \mathrm{~cm}$ were measured in fractured crystalline rock several hundred meters above the Gotthard highway tunnel in central Switzerland [10]. A series of hydrogeological problems with geotechnical and environmental impacts, causing spring discharges drying up and leading to a public protest, occurred during the construction of one of the high-speed railway tunnels between Malaga and Córdoba in south Spain [11]. Similar phenomena can also be observed during the drilling of the Firenzuola tunnel in Italy, water inrushes resulting in water table dropping below the level of the valleys and the gaining streams being transformed into losing streams or running completely dry, as did many springs, leading to severe damage to the aquatic fauna and other elements of the ecosystem [12]. 
Historically, groundwater studies associated with the design and construction of large underground structures have focused primarily on methods for control of groundwater inflows during excavation and for keeping the completed structure free of water. However, within the last several decades, the impacts of such activities on environment have become a major consideration. Though the impacts on groundwater resources of an area by underground excavation may be minimized by such planned constraints as preexcavation grouting and installation of an impermeable lining of the final excavation, such measures may not be efficient for avoiding claims of environmental impacts, particularly in areas of existing water shortages and/or marginal supplies [13]. As any groundwater drawdown alters the natural hydrogeological flow system and can consequently impact groundwaterdependent vegetation, surface streams, lakes, wetlands, and associated aquatic ecosystems, as well as springs and wells, the wise approach is to assess the potential hydrological and ecological impact of a tunnel before building it and take appropriate measures to minimize the impact [12].

As mentioned above, groundwater inflow is one of the most complicated problems which can pose a serious risk and induce impacts on groundwater environment during the tunnel excavation. Accordingly, a number of measures must be adopted to minimize these effects. Appropriate measures can only be taken once the impacts are correctly identified, but it is a difficult task to obtain the correct identification [14]. Fortunately, some relative researches are trying to do this. For instance, a quantitative evaluation of hydrogeological impacts produced by a tunnel of $3 \mathrm{~m}$ in diameter and over $7 \mathrm{~km}$ in length in the surroundings of the city of Ferrol, NW of Spain, was assessed by means of calculating the hydrogeological behaviors before and after the tunnel excavation using water balance models, and then a comparison was made to allow for the quantitative evaluation of the changes in groundwater flow and the variation in the amount of water corresponding to each component of the model [14]; Tracer tests using uranine and sulforhodamine $\mathrm{G}$ and hydrological observations consisting of springs and streams were adopted to evaluate the effects of tunnel drainage on groundwater and surface waters in the Northern Apennines, Italy [12]; Yang et al. [15] utilized a numerical method and MODFLOW codes to simulate groundwater flow pattern in the tunnel area and determine the impact of tunneling excavation on hydrogeological environment in a regional area around the tunnel and a local hot springs area, at the "Tseng-Wen Reservoir Transbasin Diversion Project," in Taiwan.

Since the hydrologic and geologic system are very rare to be completely understood due to their complexity and heterogeneity, there are many difficulties and uncertainties existing in identifying the impacts caused by tunnel excavation on groundwater environment. Compared to problems, such as time delay and increase in costs, and losses to ecosystem and society, induced by drainage from tunnel, it is very essential to make an assessment of the negative effects caused by tunnel excavation prior to constructing it. Despite the fact that some efforts have been made to try achieving this goal, more works should be done to enrich the related researches.
This study presented in this paper focuses on evaluating the influence resulting from tunnel excavation on groundwater environment, by means of employing an indicator system proposed by Liu [16]. The procedure presented in this paper is applied to a case study of the Tongluoshan tunnel constructed in southwest China, where the karstification is well developed [17]. In order to completely understand the impacts caused by the excavation of Tongluoshan tunnel, some representative hydrological points and drainage from tunnel as well as precipitation in the tunnel area have been observed during most of the construction period.

\section{Methodology}

2.1. Indicator System for Assessment of the Influence Caused by Tunnel Construction. Water inflow is known as one of the most challenging problems during the tunnel construction, and many other hydrological and geological troubles such as regional water table drawdown, surface subsidence, and wells and springs drying up are induced by it. In order to assess the impacts caused by tunnel excavation on groundwater environment, indicators that closely related to water inflow into tunnel should be firstly taken into consideration. As both mining and tunneling are subsurface activities encountering the risk and damage produced by water inflow $[1,18]$, the same attention should be paid to the factors controlling water inrush to mine.

As concluded by Liu [16], the factors affecting water inflow during tunnel excavation can be classified into three categories including physical geography, geology and hydrogeology, and tunnel engineering. Each category can also be subdivided into several indicators which extremely explain how this category impacts tunnel inflow. In the category of physical geography, seven indicators such as average annual rainfall, average annual evaporation, area of catchment zone, coefficient of rainfall infiltration, relationship between the tunnel and geomorphology, capacities of reservoirs and lakes on the ground, and flow of surface rivers are included. It is necessary to note that catchment area does not always refer to the whole area of the hydrogeological unit that tunnel is located in but means a zone which collects water from precipitation and contributes to water inflow. Another source of water inflow is surface water, which should not be ignored because of its powerful ability to supply tunnel with abundant water. All the surface water contributing to water inflow should be taken into consideration when quantifying the indicators including capacities of reservoirs and lakes on the ground and flow of surface rivers. The category of geology and hydrogeology is composed of seven indicators too, which are carbonate rocks exposure ratio, water yield properties of the aquifers, water pressure on the tunnel, development of folds, development of fracture zones, formation lithology, and location of tunnel in horizontal and vertical hydrodynamic zoning of groundwater. The last category, tunnel engineering, consists of length of tunnel, area of disturbed range, construction method, burial depth of tunnel, and measures for prevention of groundwater flowing into tunnel. It is worth noting that water inflow does not always increase or decrease over burial depth of tunnel, but 
a special range of depths may be suitable for groundwater flowing toward tunnel.

The structure of the indicator system constructed by Liu [16] aiming at assessing the negative effects caused by tunnel excavation can be seen in Table 1 .

2.2. Fuzzy Comprehensive Assessment. The concept of fuzzy sets describing imprecision or vagueness was introduced by Zadeh [19]. Fuzzy logic where an element can belong partially to several subsets may be regarded as an extension of classical Boolean logic where belonging or not to a set is mutually exclusive. It simplifies the process of taking decisions by simulating the way of reasoning of a human expert in environments characterized by uncertainty and imprecision. Fuzzy evaluation methods process all the components according to predetermined weights and decrease the fuzziness by using the membership function; therefore, the sensitivity of fuzzy evaluation is quite high compared to other index evaluation techniques [20-22].

The following procedure describes fuzzy comprehensive assessment [21].

(a) Selection of Factor Set U. Consider

$$
U=\left\{u_{i}\right\}, \quad i=1,2, \ldots, n,
$$

where $n$ is the number of selected evaluation factors. In this study, 19 indicators listed in Table 1 are selected to build the factor set; in other words, $n=19$.

(b) Construction of Evaluation Criteria Set V. Consider

$$
V=\left\{v_{j}\right\}, \quad j=1,2, \ldots, m
$$

where $m$ is the number of evaluation criteria categories and $v_{j}$ is the threshold of the $j$ th criteria category. In the present study, outputs of the assessment are classified into five grades shown in Table 2, along with corresponding evaluation criteria of each indicator. From grade 1 to grade 5, the extent of groundwater environment influenced by tunnel construction ranges from very weak to very strong.

(c) Establishment of Membership Functions. In fuzzy logic, the set $A$ is defined in terms of its membership function by

$$
A=\left\{\left(f_{A}(x)\right), x \in X, f_{A}(x) \in[0,1]\right\}
$$

where $X$ is a domain, with a generic element of $X$ denoted by $x, f_{A}$ is the membership function of the set $A$, which maps the domain $X$ onto the interval [ 01 1], and $f_{A}(x)$ represents the degree that $x$ belongs to set $A$. $x$ is a full member of $A$ when $f_{A}(x)=1$, not member of $A$ when $f_{A}(x)=0$, and a partial member of $A$ when $f_{A}(x)=(0,1)$.

The membership function of each factor to the assessment criteria at each grade can be described quantitatively by a set of formulae as follows (4) (Note: if a big value represents a small contribution to water inrush and problems induced by it, then the direction of the inequality in the conditions should be reversed):

$$
\begin{aligned}
& f_{i j}\left(x_{i}\right)= \begin{cases}0 & x_{i}>v_{i(j+1)}, \\
\frac{\left(v_{i(j+1)}-x_{i}\right)}{\left(v_{i(k+1)}-v_{i k}\right)} & v_{i j} \leq x_{i} \leq v_{i(j+1)}, \quad j=1, \\
1 & x_{i}<v_{i j},\end{cases} \\
& f_{i j}\left(x_{i}\right)= \begin{cases}0 & x_{i}>v_{i(j+1)}, \quad x_{i}<v_{i(j-1)}, \\
\frac{\left(x_{i}-v_{i(j-1)}\right)}{\left(v_{i j}-v_{i(j-1)}\right)} & v_{i(j-1)} \leq x_{i} \leq v_{i j}, \\
\frac{\left(v_{i(j+1)}-x_{i}\right)}{\left(v_{i(j+1)}-v_{i j}\right)} & v_{i j} \leq x_{i} \leq v_{i(j+1)},\end{cases} \\
& f_{i j}\left(x_{i}\right)= \begin{cases}0 & x_{i}<v_{i(j-1)}, \\
\frac{\left(x_{i}-v_{i(j-1)}\right)}{\left(v_{i j}-v_{i(j-1)}\right)} & v_{i(j-1)} \leq x_{i} \leq v_{i j}, \quad j=5, \\
1 & x_{i}>v_{i j}, \quad j, 4,\end{cases}
\end{aligned}
$$

where $i$ is the number of evaluation factors $(i=1,2,3), j$ is the number of assessment criteria levels $(j=1,2,3,4,5), x_{i}$ is the actual value of evaluation factor $i, v_{i j}, v_{i(j-1)}, v_{i(j+1)}$ is the assessment criteria threshold of the $i$ th assessment factor at level $j, j-1, j+1$, respectively, and $f_{i j}\left(x_{i}\right)$ is the membership degree of assessment factor $i$ at level $j$.

(d) Calculation of Fuzzy Relation Matrix R. Substituting the data of each indicator and the gradation criteria into the membership function listed above, the fuzzy matrix $R$ can be expressed as

$$
R=\left[\begin{array}{cccc}
r_{11} & r_{12} & \cdots & r_{1 m} \\
r_{21} & r_{22} & \cdots & r_{2 m} \\
\vdots & \vdots & \vdots & \vdots \\
r_{n 1} & r_{n 2} & \cdots & r_{n m}
\end{array}\right]
$$

where $r_{i j}(i=1,2, \ldots, n ; j=1,2, \ldots, m)$ is the membership degree of the $i$ th assessment parameter at the $j$ th level.

(e) Determination of Weight Set W. Consider

$$
W=\left\{w_{i}\right\}, \quad i=1,2, \ldots, n,
$$

where $n$ is the number of selected evaluation factors and $w_{i}$ is the weight of $i$ th factor indicating the relative importance.

Determination of the relative weight of each indicator is important for making an appropriate assessment. 10 experts and professors engaged in hydrological and environmental studies coming from home and broad were invited to identify the relative importance of each category and indicator according to their knowledge and experience. After obtaining 
TABLE 1: Indicator system for assessment of the negative effects caused by tunnel excavation on groundwater environment [16].

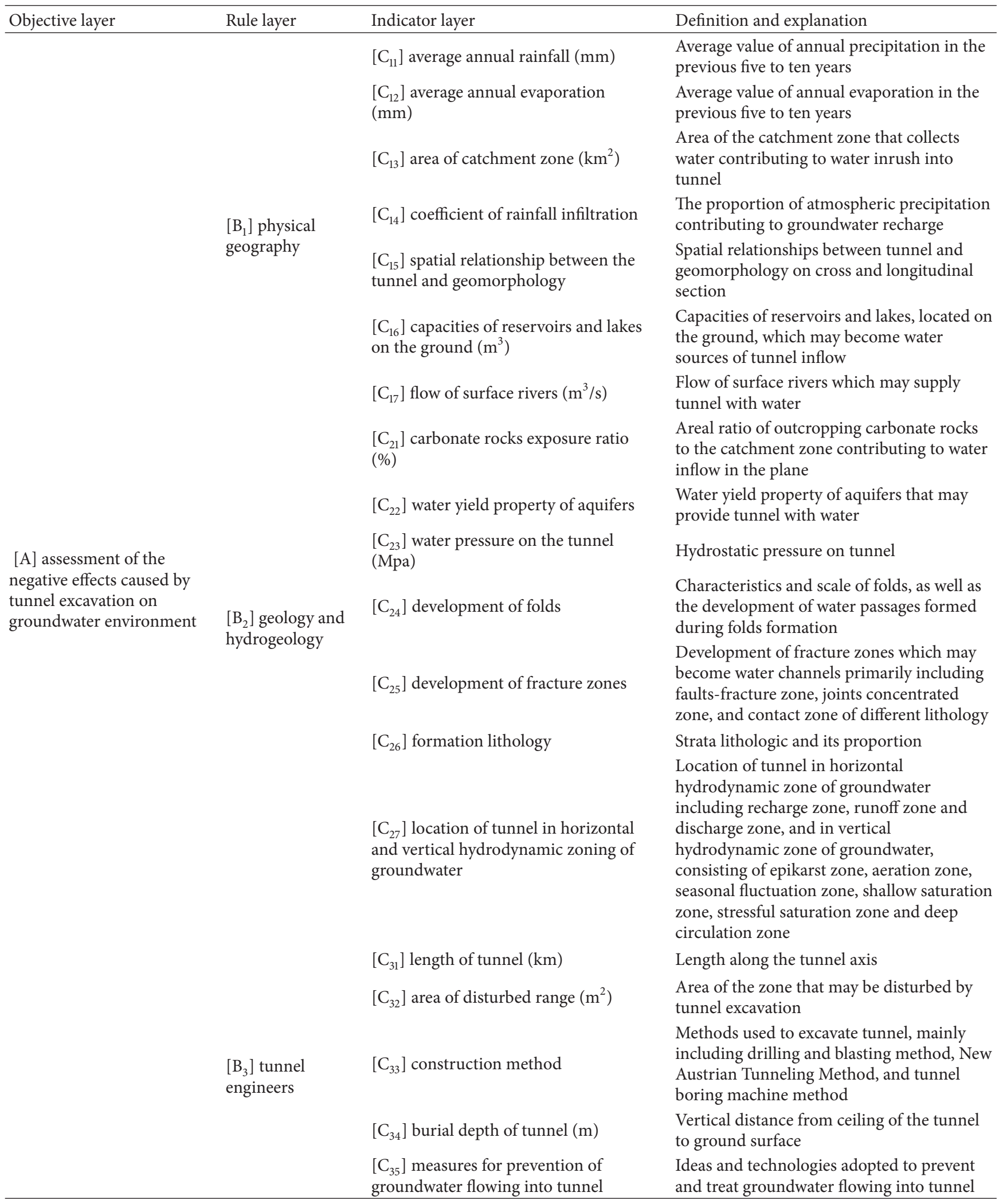


TABLE 2: Criteria for assessment of the negative effects caused by tunnel excavation on groundwater environment [16].

\begin{tabular}{|c|c|c|c|c|c|}
\hline \multirow{2}{*}{ Indicator } & \multicolumn{5}{|c|}{ Criteria } \\
\hline & Very weak & Weak & Moderate & Strong & Very strong \\
\hline $\begin{array}{l}{\left[\mathrm{C}_{11}\right] \text { average annual rainfall }} \\
(\mathrm{mm})\end{array}$ & $<600$ & $600 \sim 800$ & $800 \sim 1000$ & $1000 \sim 1600$ & $>1600$ \\
\hline $\begin{array}{l}{\left[\mathrm{C}_{12}\right] \text { average annual }} \\
\text { evaporation }(\mathrm{mm})\end{array}$ & $>800$ & $600 \sim 800$ & $500 \sim 600$ & $400 \sim 500$ & $<400$ \\
\hline $\begin{array}{l}{\left[\mathrm{C}_{13}\right] \text { area of catchment }} \\
\text { zone }\left(\mathrm{km}^{2}\right)\end{array}$ & $<5$ & $5 \sim 10$ & $10 \sim 30$ & $30 \sim 50$ & $>50$ \\
\hline $\begin{array}{l}{\left[\mathrm{C}_{14}\right] \text { coefficient of rainfall }} \\
\text { infiltration }\end{array}$ & $<0.05$ & $0.05 \sim 0.15$ & $0.15 \sim 0.30$ & $0.30 \sim 0.50$ & $>0.50$ \\
\hline $\begin{array}{l}{\left[\mathrm{C}_{15}\right] \text { spatial relationship }} \\
\text { between the tunnel and } \\
\text { geomorphology }\end{array}$ & $\begin{array}{l}\text { Other (such as flat, } \\
\text { protruding) }\end{array}$ & $\begin{array}{c}\text { Flat and } \\
\text { basin-shaped }\end{array}$ & $\begin{array}{l}\text { Angular space and } \\
\text { river crossing }\end{array}$ & $\begin{array}{l}\text { Side below the } \\
\text { valley and river } \\
\text { crossing }\end{array}$ & $\begin{array}{l}\text { Right below the } \\
\text { valley and river } \\
\text { crossing }\end{array}$ \\
\hline $\begin{array}{l}{\left[\mathrm{C}_{16}\right] \text { capacities of }} \\
\text { reservoirs and lakes on the } \\
\text { ground }\left(\mathrm{m}^{3}\right)\end{array}$ & $<1$ & $1 \sim 10$ & $10 \sim 50$ & $50 \sim 300$ & $>300$ \\
\hline $\begin{array}{l}{\left[\mathrm{C}_{17}\right] \text { flow of surface rivers }} \\
\left(\mathrm{m}^{3} / \mathrm{s}\right)\end{array}$ & $<0.1$ & $0.1 \sim 0.5$ & $0.5 \sim 2.0$ & $2.0 \sim 10.0$ & $>10.0$ \\
\hline $\begin{array}{l}{\left[\mathrm{C}_{21}\right] \text { carbonate rocks }} \\
\text { exposure ratio }(\%)\end{array}$ & $<30$ & $30 \sim 50$ & $50 \sim 70$ & $70 \sim 90$ & $>90$ \\
\hline $\begin{array}{l}{\left[\mathrm{C}_{22}\right] \text { water yield property }} \\
\text { of aquifers }\end{array}$ & $<5$ & $5 \sim 10$ & $10 \sim 15$ & $15 \sim 20$ & $>20$ \\
\hline $\begin{array}{l}{\left[\mathrm{C}_{23}\right] \text { water pressure on the }} \\
\text { tunnel (Mpa) }\end{array}$ & $<0.5$ & $0.5 \sim 1.0$ & $1.0 \sim 3.0$ & $3.0 \sim 5.0$ & $>5.0$ \\
\hline$\left[\mathrm{C}_{24}\right]$ development of folds & No folds & $\begin{array}{l}\text { Folds with } \\
\text { undeveloped } \\
\text { fissure }\end{array}$ & $\begin{array}{c}\text { Folds with } \\
\text { moderately } \\
\text { developed fissure }\end{array}$ & $\begin{array}{c}\text { Folds with } \\
\text { developed fissure }\end{array}$ & $\begin{array}{c}\text { Folds with } \\
\text { developed faults }\end{array}$ \\
\hline $\begin{array}{l}{\left[\mathrm{C}_{25}\right] \text { development of }} \\
\text { fracture zones }\end{array}$ & Rarely developed & Poorly developed & $\begin{array}{l}\text { Moderately } \\
\text { developed }\end{array}$ & Developed & Well developed \\
\hline$\left[\mathrm{C}_{26}\right]$ formation lithology & $\begin{array}{l}\text { Mudstone, shale, } \\
\text { or clay }\end{array}$ & $\begin{array}{l}\text { Sandstone or fine } \\
\text { sandstone }\end{array}$ & $\begin{array}{l}\text { Granite or igneous } \\
\text { rock }\end{array}$ & Metamorphic rock & $\begin{array}{c}\text { Soluble rocks } \\
\text { including } \\
\text { limestone, } \\
\text { dolomite, and so } \\
\text { forth }\end{array}$ \\
\hline $\begin{array}{l}{\left[\mathrm{C}_{27}\right] \text { location of tunnel in }} \\
\text { horizontal and vertical } \\
\text { hydrodynamic zoning of } \\
\text { groundwater }\end{array}$ & $\begin{array}{l}\text { Recharge area in } \\
\text { horizontal and } \\
\text { unsaturated zone } \\
\text { in vertical zoning }\end{array}$ & $\begin{array}{l}\text { Recharge area in } \\
\text { horizontal and } \\
\text { seasonal } \\
\text { fluctuation zone in } \\
\text { vertical zoning }\end{array}$ & $\begin{array}{l}\text { Runoff area in } \\
\text { horizontal and } \\
\text { shallow saturation } \\
\text { zone or deep } \\
\text { circulation zone in } \\
\text { vertical zoning }\end{array}$ & $\begin{array}{l}\text { Runoff area in } \\
\text { horizontal and } \\
\text { stressful saturation } \\
\text { zone in vertical } \\
\text { zoning }\end{array}$ & $\begin{array}{l}\text { Discharge area in } \\
\text { horizontal zoning }\end{array}$ \\
\hline$\left[\mathrm{C}_{31}\right]$ length of tunnel $(\mathrm{km})$ & $<1.0$ & $1.0 \sim 3.0$ & $3.0 \sim 10.0$ & $10.0 \sim 30.0$ & $>30.0$ \\
\hline $\begin{array}{l}{\left[\mathrm{C}_{32}\right] \text { area of disturbed }} \\
\text { range }\left(\mathrm{m}^{2}\right)\end{array}$ & $<50$ & $50 \sim 120$ & $120 \sim 250$ & $250 \sim 350$ & $>350$ \\
\hline$\left[\mathrm{C}_{33}\right]$ construction method & $\begin{array}{l}\text { Tunnel boring } \\
\text { machine method }\end{array}$ & $\begin{array}{l}\text { New Austrian } \\
\text { Tunneling Method }\end{array}$ & $\begin{array}{l}\text { Partial excavation } \\
\text { using drilling and } \\
\text { blasting method }\end{array}$ & $\begin{array}{l}\text { Benching } \\
\text { tunneling using } \\
\text { drilling and } \\
\text { blasting method }\end{array}$ & $\begin{array}{c}\text { Full face } \\
\text { excavation using } \\
\text { drilling and } \\
\text { blasting method }\end{array}$ \\
\hline $\begin{array}{l}{\left[\mathrm{C}_{34}\right] \text { burial depth of tunnel }} \\
(\mathrm{m})\end{array}$ & $\begin{array}{l}\text { Extremely bad for } \\
\text { water inflow }\end{array}$ & $\begin{array}{l}\text { Bad for water } \\
\text { inflow }\end{array}$ & $\begin{array}{l}\text { Moderate for water } \\
\text { inflow }\end{array}$ & $\begin{array}{l}\text { Good for water } \\
\text { inflow }\end{array}$ & $\begin{array}{l}\text { Extremely good for } \\
\text { water inflow }\end{array}$ \\
\hline $\begin{array}{l}{\left[\mathrm{C}_{35}\right] \text { measures for }} \\
\text { prevention of groundwater } \\
\text { flowing into tunnel }\end{array}$ & $\begin{array}{l}\text { Composite lining } \\
\text { and pregrouting }\end{array}$ & $\begin{array}{l}\text { Composite lining } \\
\text { and exterior } \\
\text { waterproof (or } \\
\text { postgrouting) }\end{array}$ & Composite lining & $\begin{array}{c}\text { Structural } \\
\text { self-waterproof }\end{array}$ & Drainage \\
\hline
\end{tabular}


TABLE 3: Comprehensive weights of the indicators included in the indicator system [16].

\begin{tabular}{lccccccccccc}
\hline Indicator & $\mathrm{C}_{11}$ & $\mathrm{C}_{12}$ & $\mathrm{C}_{13}$ & $\mathrm{C}_{14}$ & $\mathrm{C}_{15}$ & $\mathrm{C}_{16}$ & $\mathrm{C}_{17}$ & $\mathrm{C}_{21}$ & $\mathrm{C}_{22}$ & $\mathrm{C}_{23}$ \\
\hline Weight & 0.0535 & 0.0251 & 0.0387 & 0.0386 & 0.0539 & 0.0419 & 0.0419 & 0.0679 & 0.0705 & 0.0393 \\
\hline Indicator & $\mathrm{C}_{24}$ & $\mathrm{C}_{25}$ & $\mathrm{C}_{26}$ & $\mathrm{C}_{27}$ & $\mathrm{C}_{31}$ & $\mathrm{C}_{32}$ & $\mathrm{C}_{33}$ & $\mathrm{C}_{34}$ & $\mathrm{C}_{35}$ & \\
\hline Weight & 0.0617 & 0.0834 & 0.0781 & 0.0681 & 0.0554 & 0.0362 & 0.0477 & 0.0445 & 0.0538 & \\
\hline
\end{tabular}

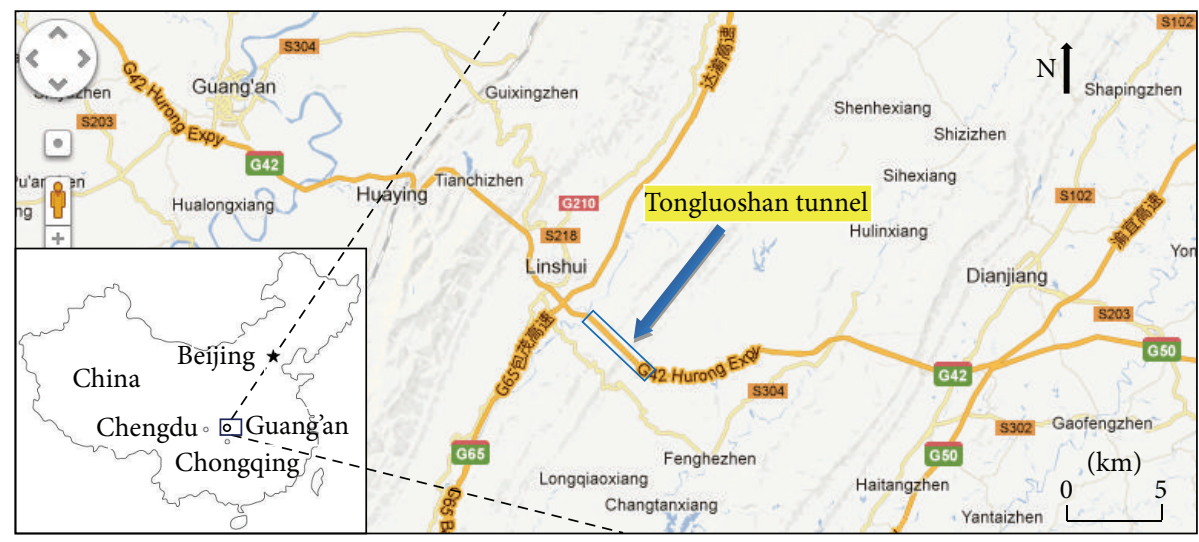

Figure 1: Location map of Tongluoshan tunnel.

the sequence and its score representing the relative importance of each factor, weight set (Table 3 ) is calculated using G1-rank correlation analysis method proposed by Guo [23].

(f) Fuzzy Matrix Composition and Determination of the Final Evaluation Result. Fuzzy composition evaluation can be performed as follows:

$$
\begin{aligned}
E & =W * R=\left(w_{1}, w_{2}, \ldots, w_{n}\right)\left[\begin{array}{ccc}
r_{11} & \cdots & r_{15} \\
\vdots & \ddots & \vdots \\
r_{n 1} & \cdots & r_{n 5}
\end{array}\right] \\
& =\left(e_{1}, e_{2}, \ldots, e_{5}\right),
\end{aligned}
$$

where $W$ and $R$ are the weight set and the fuzzy relationship matrix determined above, respectively, and $*$ is a fuzzy composite operator which is very critical to final evaluation results. In this study, average fuzzy composite operator is chosen.

\section{Case Study of Tongluoshan Tunnel}

\subsection{General Description}

3.1.1. Project Profile. Tongluoshan tunnel, with a length about $5.2 \mathrm{~km}$, located in Guangan, Southwest China (Figure 1), is a key project of Dianjiang-Linshui expressway. This project consists of two parallel tunnels, between which the distance is $30 \mathrm{~m}$ (from the adjacent walls). The thickest overburden of Tongluoshan tunnel is approximately $280 \mathrm{~m}$, while the minimum value is less than $40 \mathrm{~m}$. In order to save time, excavations were executed simultaneously from the northwest portal and southeast portal to the center during 2005 to 2008.
3.1.2. Climatic and Hydrological Features of the Tunnel Area. The tunnel area belongs to subtropics monsoon climate region, where precipitation is abundant but distributing unevenly throughout the year with the majority (70\%) falling from May to September. Annual precipitation in the tunnel area oscillates between $836.6 \mathrm{~mm}$ and $1529.8 \mathrm{~mm}$ with an average of $1215.5 \mathrm{~mm}$. Mean annual temperature in the tunnel area is $16.9^{\circ} \mathrm{C}$, with the highest and lowest daily temperature $40.4^{\circ} \mathrm{C}$ and $-3.8^{\circ} \mathrm{C}$, respectively.

Tongluoshan tunnel is located in the middle of Tongluoshan anticline, where Yulin River and Zhonghe River, belonging to the secondary and first branch of Yangtze River respectively, are the main regional surface water bodies. The major river in the tunnel area is Qingshuixi River, which originates from Jinzhong reservoir northeast of Tongluoshan tunnel and flows approximately $8.8 \mathrm{~km}$ along the axis of Tongluoshan anticline and then turns to southeast. After about $2.5 \mathrm{~km}$, it becomes a part of Zhonghe River. As is recorded, the average annual flow rate of Qingshuixi River is about $0.355 \mathrm{~m}^{3} / \mathrm{s}$ before tunnel construction.

3.1.3. Geological and Hydrogeological Characteristics of the Tunnel Area. Ground surface elevation ranges from $156 \mathrm{~m}$ to $1053 \mathrm{~m}$ in a regional scale while the northern part is higher than the southern part which Yangtze River goes through. In the tunnel area, elevation in the valley along the route of Tongluoshan anticline oscillates between $400 \mathrm{~m}$ to $550 \mathrm{~m}$, which is much smaller than that in the anticlinal flanks ranging from $600 \mathrm{~m}$ to $750 \mathrm{~m}$.

According to the preliminary geological survey undertaken by Sichuan Institute of Coal Field Geological Engineering Exploration and Design [24] and other information about tunnel design, few except a small fault $\left(F_{1}\right)$ and Tongluoshan anticline are the major geological structures developing in 


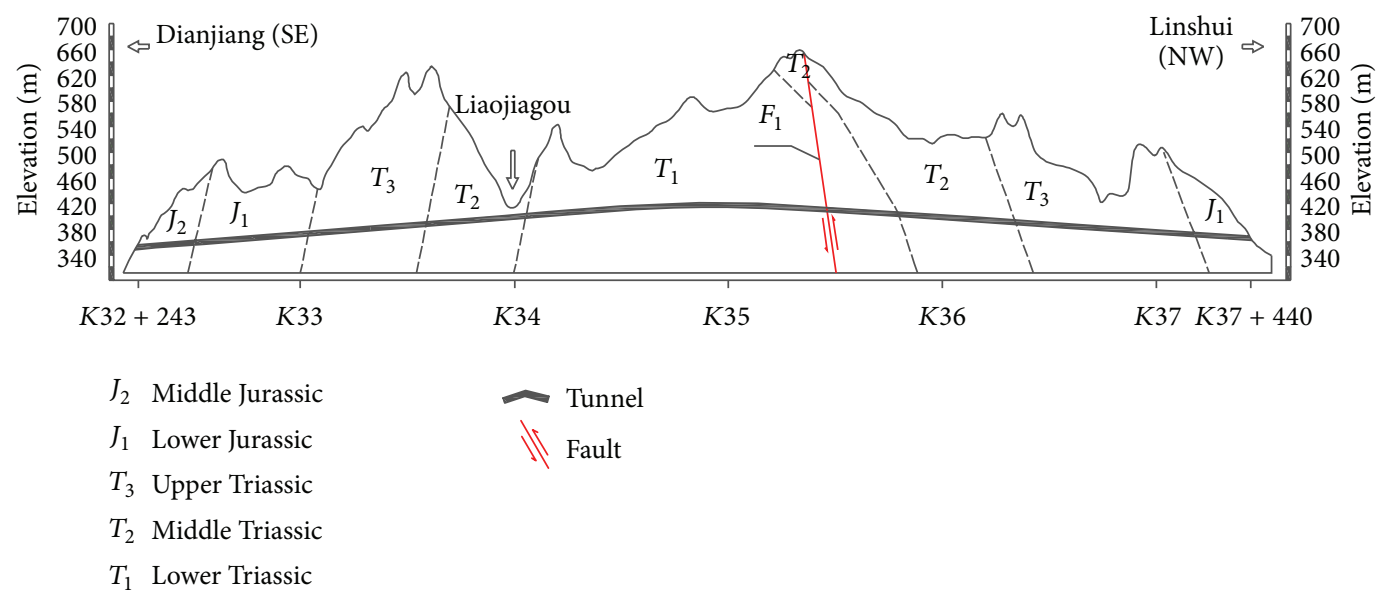

FIGURE 2: Geological profile of Tongluoshan tunnel.

the tunnel area. And the stratigraphic sequence consists of carbonate rocks of lower to middle Triassic $\left(T_{2}, T_{1}\right)$, coal measure strata of upper Triassic $\left(T_{3}\right)$, mudstone interbedded with siltstone of lower to middle Jurassic $\left(J_{2}, J_{1}\right)$, and unconsolidated sediments in Quaternary $(Q)$. The geological profile along the route is shown in Figure 2.

Tongluoshan tunnel is located in the southern part of Qingshuixi secondary hydrogeological unit, which is bounded by Yujiayakou watershed in the south, Shengouzigou watershed in the north, Yulin River in the west, and Zhonghe River in the east. This hydrogeological unit has an area about $95 \mathrm{~km}^{2}$, stretching $11.9 \mathrm{~km}$ from the southern boundary to the northern boundary, and 7 to $9 \mathrm{~km}$ in the west-east direction. According to the topography, geological structure, water-bearing medium and recharge, runoff, and discharge condition of groundwater in this hydrogeological unit, it can be divided into four aquifer systems, composed of pore water in the unconsolidated formation of Quaternary, pore and fissure water in the clasolite of Jurassic, pore and fissure water in the clasolite of upper Triassic, and carbonate water in the carbonate rocks of lower to middle Triassic. Precipitation is believed to be the primary source of recharge to the aquifers. Groundwater recharge occurs mainly from infiltration of precipitation into outcropping carbonate rocks, including stratum of lower to middle Triassic principally distributed in the core area of Tongluoshan anticline. Controlled by the coal-bearing strata and mudstone interbedded with siltstone located in the anticlinal flanks, karst groundwater generally flows towards the south and mainly discharges in terms of springs along Qingshuixi River, which is viewed as local base level of erosion.

\subsection{Fuzzy Comprehensive Evaluation of the Influence Caused by Tunnel Excavation on Groundwater Environment}

3.2.1. Quantification of the Indicators. In order to assess the negative effects caused by Tongluoshan tunnel construction on groundwater environment, the value of each indicator included in the indicator system should be previously quantified based on field investigation and technological reports related to the project such as geological survey undertaken by Sichuan Institute of Coal Field Geological Engineering Exploration and Design [24] and so on. As some indicators, for example, lithology of the formation and relation between tunnel and topography and burial depth of tunnel, are unique and of great importance to the evaluation result that may play a vital role in decision making, the work of quantification of the indicators should be done as carefully as it can be, aiming at assessing the influence as accurate as possible. Specific value representing quantification of each indicator is listed in Table 4.

3.2.2. Data Preprocessing. Data preprocessing for comprehensive evaluation is to choose an appropriate membership function which determines the membership of each indicator according to given criteria. In this case study, trapezoidal function and semitrapezoidal function (4) are chosen, because of their advantage in simple processing and smooth linking. It is noted that the standard of an indicator at each level can be described as an interval like $[a, b]$, which may have existed or will be built. And it is reasonable for determining the membership of $x$ as 1.0 when $x=(a+b) / 2$, so $v_{i j}$ in the equations (e.g., (4)) may be valued as $(a+b) / 2$. If difficulties existing in finding an upper or lower limit of some indicators, $\eta=3 \sim 5$ or $\eta=1 / 5 \sim 1 / 3$ can be multiplied to achieve this goal. After substitution of actual value quantified in Table 4 and criteria listed in Table 2 into the membership function, membership of each indictor at every level (Table 5) can be gotten, which will directly be transferred into a fuzzy matrix $R$.

3.2.3. Fuzzy Comprehensive Evaluation. When prepared, evaluation set $W$ and fuzzy matrix $R$ can be composed using average fuzzy composite operator according to (7):

$$
E=W * R=\left(w_{1}, w_{2}, \ldots, w_{19}\right)\left[\begin{array}{ccc}
r_{1,1} & \cdots & r_{1,5} \\
\vdots & \ddots & \vdots \\
r_{19,1} & \cdots & r_{19,5}
\end{array}\right]
$$


TABLE 4: Quantification of each factor included in the indicator system.

\begin{tabular}{|c|c|c|}
\hline Category & Indicator & Value of Tonluoshan tunnel \\
\hline \multirow{7}{*}{$\begin{array}{l}{\left[\mathrm{B}_{1}\right] \text { physical }} \\
\text { geography }\end{array}$} & {$\left[\mathrm{C}_{11}\right]$ average annual rainfall $(\mathrm{mm})$} & $\begin{array}{l}\text { According to rainfall records from local meteorological station, the } \\
\text { average annual precipitation is } 1215.5 \mathrm{~mm} \text { in the tunnel area. }\end{array}$ \\
\hline & $\begin{array}{l}{\left[\mathrm{C}_{12}\right] \text { average annual evaporation }} \\
(\mathrm{mm})\end{array}$ & $\begin{array}{l}\text { According to evaporation records from local meteorological station, the } \\
\text { average annual evaporation is } 959.6 \mathrm{~mm} \text { in the tunnel area. }\end{array}$ \\
\hline & {$\left[\mathrm{C}_{13}\right]$ area of catchment zone $\left(\mathrm{km}^{2}\right)$} & $\begin{array}{l}\text { Tongluoshan tunnel passes through strata consisting of carbonate rocks } \\
\text { of high permeability in the core and clastic rocks of low permeability in } \\
\text { the flanks of Tongluoshan anticline. When calculating the catchment } \\
\text { zone of tunnel inflow, a region composed of local watershed around the } \\
\text { route of tunnel in the flanks and the entire karst valley are included. } \\
\text { Total area of the catchment zone of Tongluoshan tunnel then is } \\
\text { determined to } 38.4 \mathrm{~km}^{2} \text {. }\end{array}$ \\
\hline & {$\left[\mathrm{C}_{14}\right]$ coefficient of rainfall infiltration } & $\begin{array}{l}\text { Based on the geological investigation report, infiltration coefficient of } \\
\text { rainfall in the outcropping carbonate rocks }\left(T_{1} \text { and } T_{2}\right) \text { reaches } 0.55 \text {, } \\
\text { with } 0.20 \text { in the coal measure strata }\left(T_{3}\right) \text {, while it is only } 0.054 \text { in the } \\
\text { Jurassic clastic rocks }\left(J_{1} \text { and } J_{2}\right) \text {. Due to statistics of outcrop in terms of } \\
\text { different lithology, } 44 \% \text { of them are carbonate rocks, while } 32 \% \text { are coal } \\
\text { bearing strata, and } 24 \% \text { are clastic rocks. }\end{array}$ \\
\hline & $\begin{array}{l}{\left[\mathrm{C}_{15}\right] \text { spatial relationship between the }} \\
\text { tunnel and geomorphology }\end{array}$ & $\begin{array}{l}\text { Length consisting of the section between } 32 \mathrm{~K}+700 \text { and } 34 \mathrm{~K}+200 \text { and } \\
\text { that between } 35 \mathrm{~K}+800 \text { and } 36 \mathrm{~K}+300 \text { is about } 2 \mathrm{~km} \text {, belonging to the } \\
\text { type of side below the valley and river crossing, while the rest belongs to } \\
\text { other type. }\end{array}$ \\
\hline & $\begin{array}{l}{\left[\mathrm{C}_{16}\right] \text { capacities of reservoirs and lakes }} \\
\text { on the ground }\left(\mathrm{m}^{3}\right)\end{array}$ & $\begin{array}{l}\text { There are no reservoirs and lakes within } 2 \mathrm{~km} \text { from the tunnel axis } \\
\text { except Jinzhong reservoir, which is about } 9 \mathrm{~km} \text { far from the tunnel axis, } \\
\text { storing approximately } 300 \text { thousand cubic meters. Since karstification is } \\
\text { well developed in the tunnel area and Jinzhong reservoir is the origin of } \\
\text { Qingshuixi River, it is taken into consideration from a safe point of view. }\end{array}$ \\
\hline & {$\left[\mathrm{C}_{17}\right]$ flow of surface rivers $\left(\mathrm{m}^{3} / \mathrm{s}\right)$} & $\begin{array}{l}\text { Qingshuixi River is the main surface river which may have hydraulic } \\
\text { connection with the water inflow into tunnel. }\end{array}$ \\
\hline
\end{tabular}

$\left[\mathrm{C}_{21}\right]$ carbonate rocks exposure ratio (\%)

$\left[\mathrm{C}_{22}\right]$ water yield property of aquifers

$\left[\mathrm{B}_{2}\right]$ geology and hydrogeology

\section{(Mpa)}

$\left[\mathrm{C}_{24}\right]$ development of folds

$\left[\mathrm{C}_{25}\right]$ development of fracture zones

$\left[\mathrm{C}_{26}\right]$ formation lithology

$\left[\mathrm{C}_{27}\right]$ location of tunnel in horizontal and vertical hydrodynamic zoning of groundwater

$\left[\mathrm{C}_{31}\right]$ length of tunnel $(\mathrm{km})$

$\left[\mathrm{C}_{32}\right]$ area of disturbed range $\left(\mathrm{m}^{2}\right)$

$\left[\mathrm{B}_{3}\right]$ tunnel $\quad\left[\mathrm{C}_{33}\right]$ construction method engineers

$\left[\mathrm{C}_{34}\right]$ burial depth of tunnel (m)

$\left[\mathrm{C}_{35}\right]$ measures for prevention of groundwater flowing into tunnel
As mentioned above, this ratio is about $44 \%$ in the tunnel area.

Based on the longitudinal profile of Tongluoshan tunnel, area of rocks with poor water yield property occupies $62.37 \%$, with middle standing $30.14 \%$, while the left $(7.5 \%)$ is considered as aquifer with very good water yield property.

Average water pressure on the tunnel is estimated as 1.0 MPa.

Tongluoshan anticline is the main fold developed in the tunnel area with fractures coming from geological and karstic process.

Fracture zone passed through by tunnel excavation is found moderately developed.

Based on outcrops in the tunnel area, mudstone, shale, and clay stand for $21 \%$ and sandstone and siltstone stand for $35 \%$, while carbonate rocks occupy $44 \%$.

From a regional scale, Tongluoshan tunnel is located in runoff area in horizontal and stressful saturation zone in vertical zoning.

About $5.2 \mathrm{~km}$.

About $185 \mathrm{~m}^{2}$ including two tunnels.

About $80 \%$ of the tunnel excavated by full face excavation using drilling and blasting method, while the others adopt benching tunneling using drilling and blasting method.

Burial depth between $100 \mathrm{~m}$ and $300 \mathrm{~m}$ stands for $50 \%$, while the others have a value less than $100 \mathrm{~m}$. From some statistic data and hydrogeological condition in the tunnel area, moderate level is given. Composite lining is the prevailing waterproof used by Tongluoshan tunnel, while $20 \%$ of which adopts external pregrouting. 
TABle 5: Membership of each indictor at every level calculated from quantification of Tongluoshan tunnel and the evaluation criteria.

\begin{tabular}{|c|c|c|c|c|c|}
\hline \multirow{2}{*}{ Indicator } & \multicolumn{5}{|c|}{ Grades } \\
\hline & Very weak & Weak & Moderate & Strong & Very strong \\
\hline$\left[\mathrm{C}_{11}\right]$ average annual rainfall $(\mathrm{mm})$ & 0 & 0 & 0.211 & 0.789 & 0 \\
\hline$\left[\mathrm{C}_{12}\right]$ average annual evaporation $(\mathrm{mm})$ & 0.288 & 0.712 & 0 & 0 & 0 \\
\hline$\left[\mathrm{C}_{13}\right]$ area of catchment zone $\left(\mathrm{km}^{2}\right)$ & 0 & 0 & 0.080 & 0.920 & 0 \\
\hline$\left[\mathrm{C}_{14}\right]$ coefficient of rainfall infiltration & 0.158 & 0.146 & 0.256 & 0.330 & 0.110 \\
\hline $\begin{array}{l}{\left[\mathrm{C}_{15}\right] \text { spatial relationship between the tunnel }} \\
\text { and geomorphology }\end{array}$ & 0.600 & 0 & 0 & 0.400 & 0 \\
\hline $\begin{array}{l}{\left[\mathrm{C}_{16}\right] \text { capacities of reservoirs and lakes on }} \\
\text { the ground }\left(\mathrm{m}^{3}\right)\end{array}$ & 0 & 0 & 1.000 & 0 & 0 \\
\hline$\left[\mathrm{C}_{17}\right]$ flow of surface rivers $\left(\mathrm{m}^{3} / \mathrm{s}\right)$ & 0 & 1.000 & 0 & 0 & 0 \\
\hline$\left[\mathrm{C}_{21}\right]$ carbonate rocks exposure ratio (\%) & 0 & 0.800 & 0.200 & 0 & 0 \\
\hline$\left[\mathrm{C}_{22}\right]$ water yield property of aquifers & 0.624 & 0 & 0.301 & 0 & 0.075 \\
\hline$\left[\mathrm{C}_{23}\right]$ water pressure on the tunnel $(\mathrm{Mpa})$ & 0 & 0.800 & 0.200 & 0 & 0 \\
\hline$\left[\mathrm{C}_{24}\right]$ development of folds & 0 & 0 & 0 & 1.000 & 0 \\
\hline$\left[\mathrm{C}_{25}\right]$ development of fracture zones & 0 & 0 & 1.000 & 0 & 0 \\
\hline$\left[\mathrm{C}_{26}\right]$ formation lithology & 0.210 & 0.350 & 0 & 0 & 0.440 \\
\hline $\begin{array}{l}{\left[\mathrm{C}_{27}\right] \text { location of tunnel in horizontal and }} \\
\text { vertical hydrodynamic zoning of } \\
\text { groundwater }\end{array}$ & 0 & 0 & 0 & 1.000 & 0 \\
\hline$\left[\mathrm{C}_{31}\right]$ length of tunnel $(\mathrm{km})$ & 0 & 0.289 & 0.711 & 0 & 0 \\
\hline$\left[\mathrm{C}_{32}\right]$ area of disturbed range $\left(\mathrm{m}^{2}\right)$ & 0 & 0 & 1.000 & 0 & 0 \\
\hline$\left[\mathrm{C}_{33}\right]$ construction method & 0 & 0 & 0 & 0.200 & 0.800 \\
\hline$\left[\mathrm{C}_{34}\right]$ burial depth of tunnel $(\mathrm{m})$ & 0 & 0 & 1.000 & 0 & 0 \\
\hline $\begin{array}{l}{\left[\mathrm{C}_{35}\right] \text { measures for prevention of }} \\
\text { groundwater flowing into tunnel }\end{array}$ & 0.200 & 0 & 0.800 & 0 & 0 \\
\hline
\end{tabular}

$$
=(0.117,0.195,0.355,0.251,0.082) \text {. }
$$

Maximum membership principle $[25,26]$ is a simple and widely used principle on the membership degree matrix. The elements in the vector of evaluation result stand for the membership degree to assessing level. According to this principle, it can be determined that the assessment result of Tongluoshan tunnel is moderate, as 0.355 is the maximum member in the evaluation result vector. Meanwhile, another weighted mean method [27] which allocates a relative rating $(1,2,3,4$, and 5 , resp.) to the five levels and uses accelerations composition method to calculate the total value is employed to perform calculations:

$$
\begin{aligned}
T= & 1 \times e_{1}+2 \times e_{2}+3 \times e_{3}+4 \times e_{4}+5 \times e_{5} \\
= & 1 \times 0.117+2 \times 0.195+3 \times 0.355+4 \times 0.251+5 \\
& \times 0.082 \\
= & 2.99 .
\end{aligned}
$$

Based on the result calculated by weighted mean method, middle level tends to be accepted because $T$ is very close to 3. Therefore, from arithmetically speaking, moderate grade is recommended as the influence level of Tongluoshan tunnel, indicating that the local groundwater environment might have suffered a medium degree of impact from the tunnel excavation.

Although the indicator system supplying us with a convenient way to evaluate the influence resulted from tunnel construction on groundwater environment, field work such as environmental investigation and hydrological monitoring is important and essential to help judge whether the assessment is appropriate or not. Some details about the procedure and result of environmental investigation and hydrological monitoring carried out in Tongluoshan tunnel area are described in the next section.

\subsection{Environmental Investigation and Hydrologic Monitoring.} Environmental investigation and hydrologic monitoring in the project area that may be affected was implemented for the early detection of environmental impacts caused by tunnel excavation. More than fifty springs, wells, and streams were found in the tunnel area during the first investigation carried in July 2005, and fifteen of them including twelve springs, one well, and two streams, which either supply people with drinking water or flow at a notable rate, were finally selected to perform a long term monitoring program. In addition, discharge from tunnel and rainfall in the project area were monitored together. Figure 3 shows the location of the observation points included in the frequent sampling protocol. 


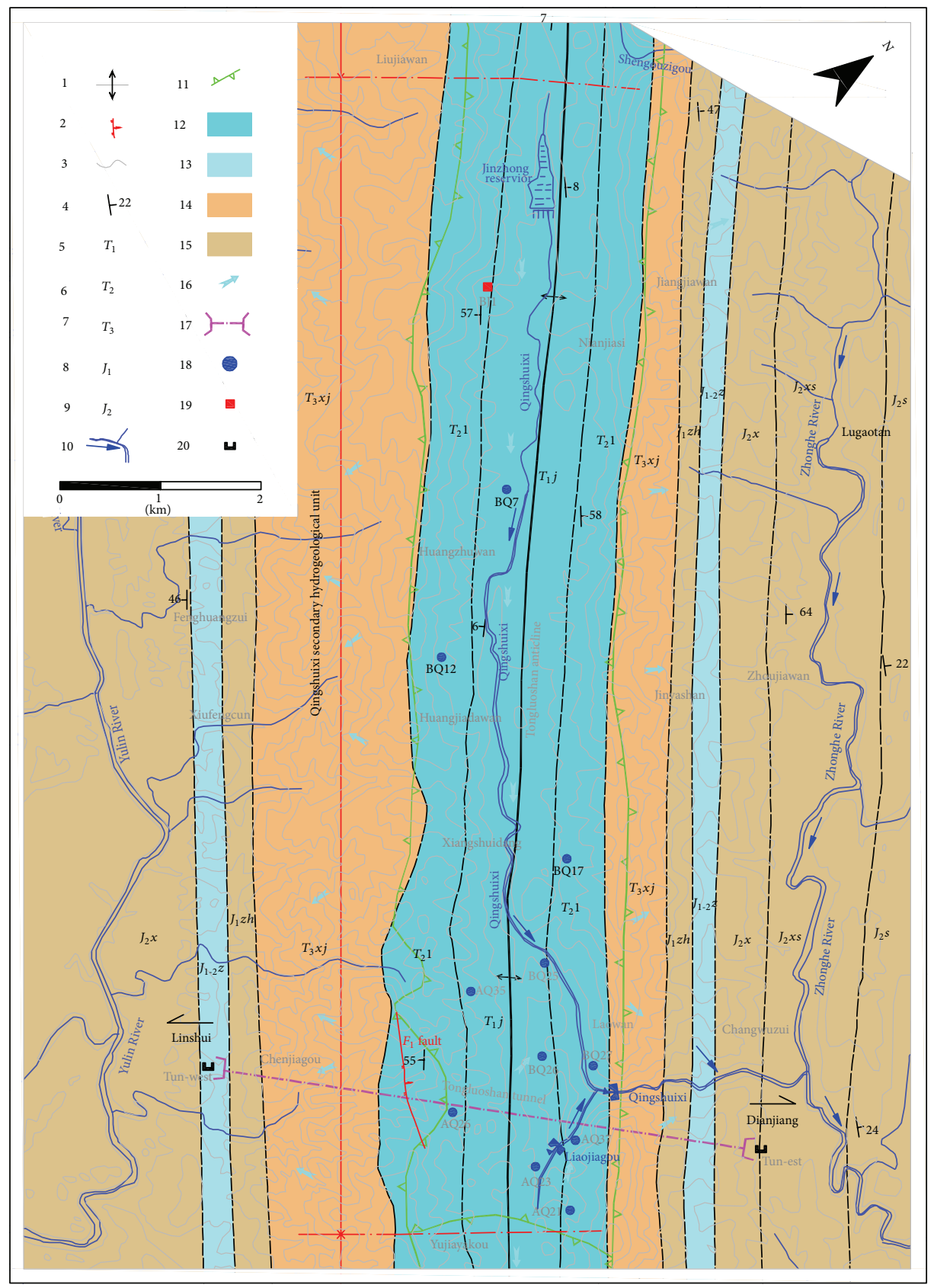

FIGURE 3: Map showing hydrogeological features and observation points in the project area. 1: anticline; 2: fault; 3: stratigraphic boundary; 4: attitude of strata; 5: lower Triassic; 6: middle Triassic; 7: upper Triassic; 8: lower Jurassic; 9: upper Jurassic; 10: river and its flow direction; 11: watershed; 12: limestone and dolomite; 13: carbonate rocks interbedded with mudstone; 14: sandstone; 15: mudstone interbedded with siltstone; 16: flow direction of groundwater; 17: tunnel; 18: spring; 19: well; 20: drainage from tunnel.

The monitoring process, lasting about 15 months from May 2006 to July 2007, was executed within the main construction period, during which daily discharge rate of tunnel and springs, flow of streams, and water table in well BJ1 were observed. In general, almost all the springs and streams as well as BJ1 respond to rainfall, with more responses from BJ1, BQ7, BQ27, AQ23, AQ37, Qingshuixi, and Liaojiagou, followed by BQ12, BQ25, AQ9, and AQ26. Another type including AQ21 and AQ35 shows evident time lag between discharge of springs and the precipitation, indicating that the fracture network recharging from rainfall and transferring groundwater to the emergence place does not work efficiently. More surprising, there are some springs which become nearly of no interest in precipitation, such as BQ17 and BQ26.

From a water balance point of view, it is believed that groundwater discharge from tunnel acting as a new flow out pattern will reduce the amount of other flow-out patterns such as springs and wells, supposing no changes happening 

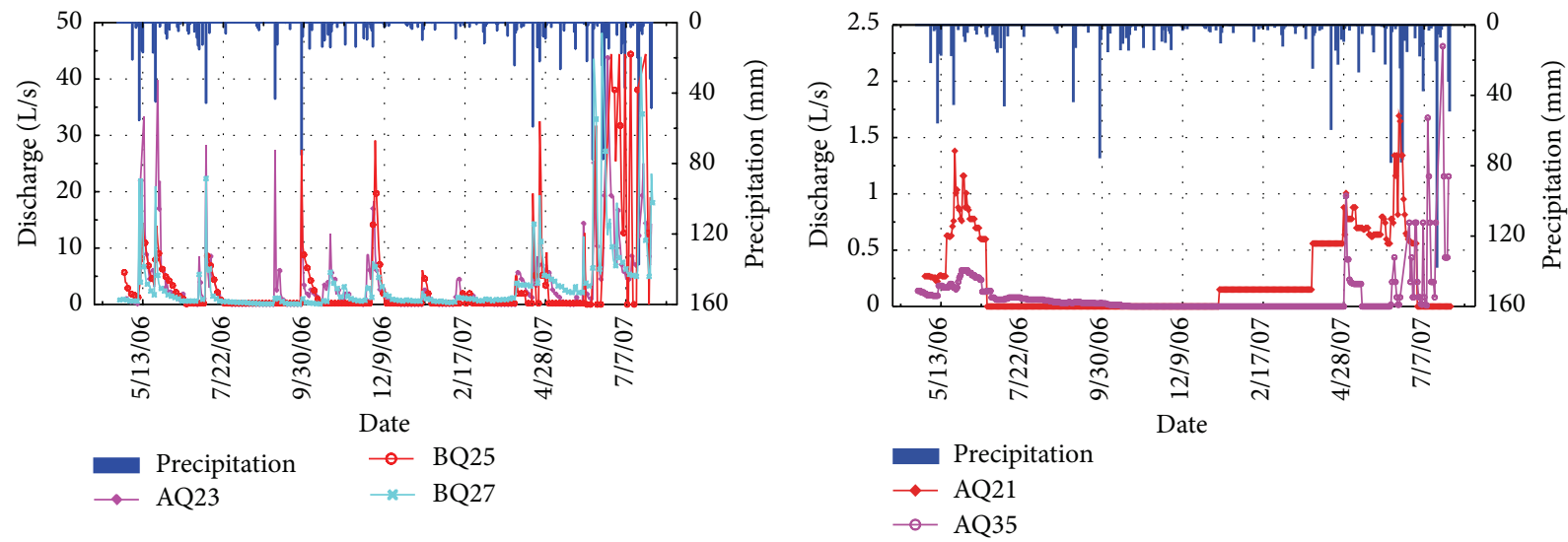

(a)

(b)

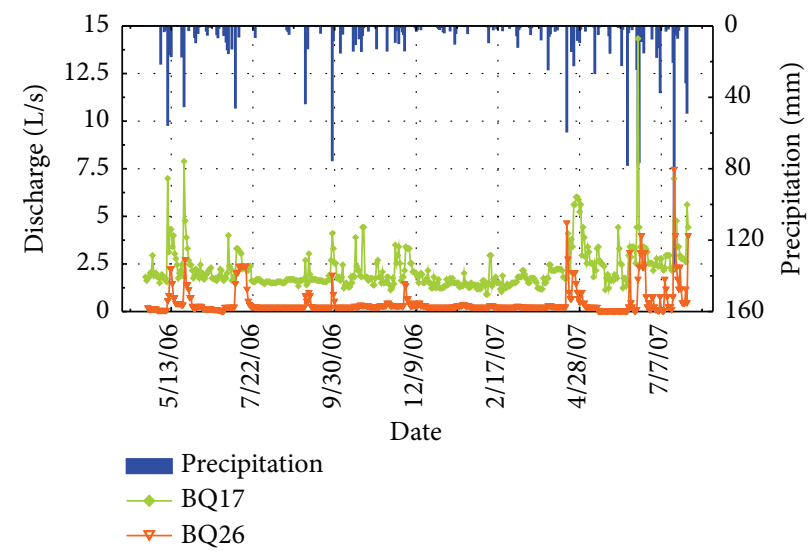

(c)

FIGURE 4: Hydrographs of the principal springs in the project area. (a) Discharge of AQ23, BQ25, and BQ27 versus time. (b) Discharge of AQ21 and AQ35 versus time. (c) Discharge of BQ26 and BQ27 versus time.

to the flow in patterns. Consequently, hydrograph of surface water and groundwater can help us to identify the influence caused by tunnel construction.

AQ23, BQ25, and BQ27 are karst springs which have never dried up in the past according to local residents, appearing in $T_{1} j$ stratum. It is obviously described in Figure 4(a) that these springs respond quickly to rainfall, especially in some periods with sufficient recharge. However, unfortunate things happen to AQ23 and BQ25 during the monitoring period. AQ23 completely dried up during June 27 to 30, 2006, July 29 to September 4, 2006, September 16 to 27,2006 , December 22, 2006, to January 11, 2007, and March 15 to April 1, 2007. BQ25 had no discharge during July 23 to September 27, 2006, October 15 to November 28, 2006, December 10, 2006, to January 10, 2007, January 18 to February 12, 2007, February 23 to April 1, 2007, and May 1 to 31,2007 . These phenomena indicate that Tongluoshan tunnel may drain groundwater which could have come to surface from AQ23 and BQ25. Compared to them, BQ27 has more luck because it had never dried up despite the fact that the minimum flow rate was about $0.1 \mathrm{~L} / \mathrm{s}$, far below the normal average $0.8 \mathrm{~L} / \mathrm{s}$.
AQ21 flowed out from an abandoned mine, which settled in $T_{3} x j$ coal bearing layer. It continuously supplied people around with groundwater for drinking prior to tunnel excavation. According to the records shown in Figure 4(b), the flow came to zero during June 22, 2006, to January 9 and July 1 to 31, 2007, in spite of adequate rainfall during January 10 to June 30, 2007. AQ35 is an epikarst spring situated in higher elevation, as is recorded in Figure 4(b); its discharge declined from $0.3 \mathrm{~L} / \mathrm{s}$ to zero using approximately 4 months and maintains this status for a long time regardless of whether rainfall occurred. Based on the situation described above, it is doubted that AQ21 and AQ35 may had been linked to tunnel construction. According to Figure 4(c), BQ17 flowed throughout the period recorded with modest discharge, even during rainy periods. This phenomenon can be attributed to the abundant storage capacity of fractures that feeding BQ17.

Liaojiagou is a branch of Qingshuixi, which is the major stream in the project area. According to Figures 5 and 4(a), both Qingshuixi and Liaojiagou bear much resemblance to AQ23, BQ25, and BQ27 in response to rainfall. But Liaojiagou, as with AQ23, did not escape influences from both local meteorological condition and tunnel excavation. They 


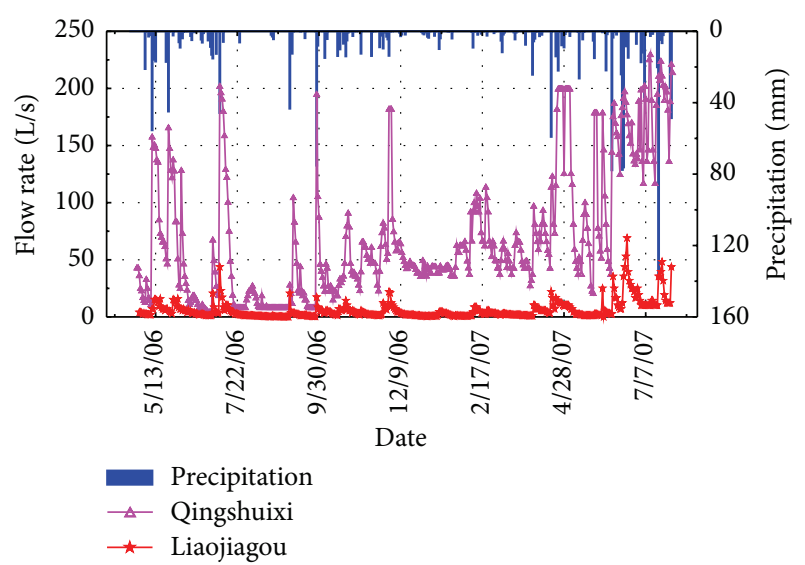

FIGURE 5: Hydrographs of Qingshuixi and Liaojiagou.

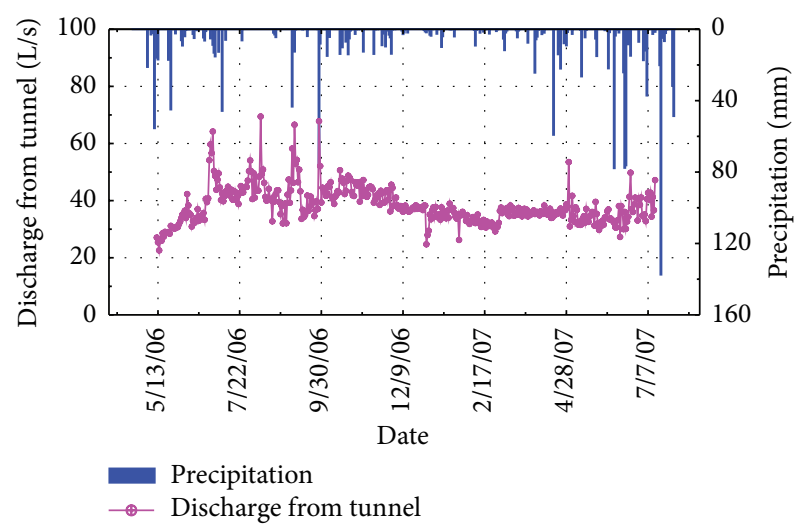

FIGURE 6: Drainage from tunnel versus time.

dried up quickly after being recharged from precipitation and continued this state for a long period. However, Qingshuixi showed strong vitality during the whole monitoring period, flowing in quite accordance with precipitation recorded in the project area without any appearance of external leakage, demonstrating that Qingshuixi has not been affected by construction of Tongluoshan tunnel.

Drainage from Tongluoshan tunnel is depicted in Figure 6, from which we can find a quick increase from $20 \mathrm{~L} / \mathrm{s}$ to $64 \mathrm{~L} / \mathrm{s}$ before June 28,2006 , and drastic oscillation between $32 \mathrm{~L} / \mathrm{s}$ and $69 \mathrm{~L} / \mathrm{s}$ in the next three months, followed by pediocratic changes between $30 \mathrm{~L} / \mathrm{s}$ and $40 \mathrm{~L} / \mathrm{s}$. In general, tunnel inflow had an obvious ascending tendency when encountering carbonate rocks and performed a slow downtrend after drainage of groundwater stored in the fracture network around tunnel and grouting to prevent water inrush.

3.4. Determination of an Impact. While employing the indicator system to assess the negative effects caused by Tongluoshan tunnel construction on groundwater environment, maximum membership principle method makes an assessment result of medium level as 0.355 is the maximum member in the evaluation result vector, and weighted mean method gives nearly the same result because $T$ is very close to 3 . From a mathematic point of view, moderate grade is recommended as the influence level of Tongluoshan tunnel.

In order to verify whether the assessment is reasonable or not, environmental investigation and hydrological monitoring program was carried out in the tunnel area. Twelve springs, one well, and two streams, which either supply people with drinking water or flow at a notable rate, were selected to perform a 15 -month-long monitoring process and so were the discharge from tunnel and rainfall in the project area. During the main construction period, some of the monitoring points near the tunnel axis, such as AQ21, AQ23, AQ35, and BQ27, have been strongly impacted by tunnel construction and lasting drainage of groundwater. Most of them have never dried up and maintained base flow even in the dry season, but an obvious decline was found throughout the monitoring period. Though strong relation exists between most of the monitoring points and precipitation, it seems that groundwater drainage from tunnel plays a nonnegligible role because some of the monitoring points repeatedly ran dry during the main construction period despite being recharged by precipitation. Based on the information fed back from environmental investigation and hydrologic monitoring carried out during the main construction period, approximately $1 \mathrm{~km}$ from the tunnel axis (not including BQ25 which is partly fed by upstream surface water) is inferred as the sphere of influence in the middle karst section of Tongluoshan tunnel, which is less than other typical karst tunnel, such as Yuanliangshan tunnel and Geleshan tunnel $[8,16]$.

As is analyzed above, moderate grade influence on groundwater system is considered to be an appropriate result for Tongluoshan tunnel construction for the reason that (a) assessment made from the indicator system and fuzzy comprehensive method falls into middle level; (b) some of the monitoring points near the tunnel axis which have never dried up and maintained base flow even in the dry season experienced an obvious decline throughout the monitoring period, revealing that the local groundwater environment might have been impacted by the tunnel excavation; (c) the sphere of influence in the middle karst section of Tongluoshan tunnel approaches approximately $1 \mathrm{~km}$ from the tunnel axis, which is less than other typical karst tunnels. So, there is no doubt that the local groundwater environment had been impacted by the excavation of Tongluoshan tunnel, but the influence level is moderate.

\section{Conclusion and Outlook}

Making an assessment on how the construction would affect local groundwater environment before excavation is of vital importance to line selection of tunnel. This study adopted an indicator system and fuzzy comprehensive evaluation method to identify the influence caused by Tongluoshan tunnel construction on groundwater environment. It was shown that maximum membership stood in the middle of the evaluation result set and 3.2 was scored by relative rating weighted calculation, indicating that excavation of Tongluoshan tunnel had influenced the local groundwater environment at a moderate degree. Based on the information 
fed back from environmental investigation and hydrologic monitoring carried out during the main construction period, flow of some springs and Liaojiagou stream located beside the tunnel route was found experiencing an apparent decline; even worse, AQ21, AQ23, AQ35, and BQ25 had dried up for a relatively long time because of lower precipitation during 2006 than that in the past and drainage from tunnel resulting in reduction of other flow-out patterns in water balance.

Through this practice, it can be concluded that making an assessment using the indicator system and fuzzy comprehensive evaluation method would supply us with a simple way to understand the situation that may happen to groundwater environment during tunnel construction and can help us to choose an optimized channel through which less disruption related to water inflow may occur. Once the tunnel location is determined and prepared to construction, we can also use the indicator system to evaluate the potential groundwater environmental impact before building it and take appropriate measures to minimize the impact. The major differences between a building tunnel and a built tunnel focus on two indicators including "construction method" and "measures for prevention of groundwater flowing into tunnel." Taking Tongluoshan tunnel as an example and setting "boring machine method" and "drainage with composite lining" as the initial condition, a result vector of $0.106,0.195,0.312$, 0.242 , and 0.145 indicates that the influence level partly tends to be strong, because the gap between the maximum member and the second maximum member falls to 0.07 , smaller than 0.1 . In order to minish the potential impact, measurements such as previous and postgrouting from tunnel, pregrouting from surface, and partial excavation using drilling and blasting method were taken at some sections with high risk of water irruption, reducing the influence level and impact on groundwater environment to some extent.

\section{Conflict of Interests}

The authors declare that there is no conflict of interests regarding the publication of this paper.

\section{Acknowledgments}

This research was supported by Communications Department of Sichuan Province, Sichuan Dayu Expressway Construction and Development Company Limited (2006-G02), and the Fundamental Research Funds for the Central Universities (2682015CX020). Many thanks should be given to the team members related to this program, for their help with field investigation and data collection and processing.

\section{References}

[1] H. R. Zarei, A. Uromeihy, and M. Sharifzadeh, "Identifying geological hazards related to tunneling in carbonate karstic rocks-Zagros, Iran," Arabian Journal of Geosciences, vol. 5, no. 3, pp. 457-464, 2012.

[2] C. Butscher, P. Huggenberger, and E. Zechner, "Impact of tunneling on regional groundwater flow and implications for swelling of clay-sulfate rocks," Engineering Geology, vol. 117, no. 3-4, pp. 198-206, 2011.

[3] U. Chiocchini and F. Castaldi, "The impact of groundwater on the excavation of tunnels in two different hydrogeological settings in central Italy," Hydrogeology Journal, vol. 19, no. 3, pp. 651-669, 2011.

[4] J.-H. Hwang and C.-C. Lu, "A semi-analytical method for analyzing the tunnel water inflow," Tunnelling and Underground Space Technology, vol. 22, no. 1, pp. 39-46, 2007.

[5] S. Alija, F. J. Torrijo, and M. Quinta-Ferreira, "Geological engineering problems associated with tunnel construction in karst rock masses: the case of Gavarres tunnel (Spain)," Engineering Geology, vol. 157, pp. 103-111, 2013.

[6] M. J. Day, "Karstic problems in the construction of Milwaukee's Deep Tunnels," Environmental Geology, vol. 45, no. 6, pp. 859863, 2004.

[7] L. Schwarz, I. Reichl, H. Kirschner, and K. P. Robl, "Risks and hazards caused by groundwater during tunnelling: geotechnical solutions used as demonstrated by recent examples from Tyrol, Austria," Environmental Geology, vol. 49, no. 6, pp. 858-864, 2006.

[8] L. W. Jiang, Y. J. Yi, and Z. M. Jia, "Research on characteristics and formation mechanism of great deep buried infilled caves at Maoba syncline in the Yuanliangshan railway tunnel," Journal of Railway Engineering Society, no. 4, pp. 53-60, 2007 (Chinese).

[9] D.-J. Tseng, B.-R. Tsai, and L.-C. Chang, "A case study on ground treatment for a rock tunnel with high groundwater ingression in Taiwan," Tunnelling and Underground Space Technology, vol. 16, no. 3, pp. 175-183, 2001.

[10] C. Zangerl, E. Eberhardt, and S. Loew, "Ground settlements above tunnels in fractured crystalline rock: numerical analysis of coupled hydromechanical mechanisms," Hydrogeology Journal, vol. 11, no. 1, pp. 162-173, 2003.

[11] J. Gisbert, A. Vallejos, A. González, and A. Pulido-Bosch, "Environmental and hydrogeological problems in karstic terrains crossed by tunnels: a case study," Environmental Geology, vol. 58, no. 2, pp. 347-357, 2009.

[12] V. Vincenzi, A. Gargini, and N. Goldscheider, "Using tracer tests and hydrological observations to evaluate effects of tunnel drainage on groundwater and surface waters in the Northern Apennines (Italy)," Hydrogeology Journal, vol. 17, no. 1, pp. 135150, 2009.

[13] P. M. Attanayake and M. K. Waterman, "Identifying environmental impacts of underground construction," Hydrogeology Journal, vol. 14, no. 7, pp. 1160-1170, 2006.

[14] J. R. Raposo, J. Molinero, and J. Dafonte, "Quantitative evaluation of hydrogeological impact produced by tunnel construction using water balance models," Engineering Geology, vol. 116, no. 3-4, pp. 323-332, 2010.

[15] F.-R. Yang, C.-H. Lee, W.-J. Kung, and H.-F. Yeh, “The impact of tunneling construction on the hydrogeological environment of 'Tseng-Wen Reservoir Transbasin Diversion Project' in Taiwan," Engineering Geology, vol. 103, no. 1-2, pp. 39-58, 2009.

[16] J. Liu, Study on the evaluation system of negative effects on groundwater environment resulted by tunnel construction in karst area [Ph.D. thesis], Southwest Jiaotong University, Chengdu, China, 2011, (Chinese).

[17] D. X. Yuan, Karstology of China, Geological Publishing House, Beijing, China, 1994, (Chinese).

[18] J. F. Durand, "The impact of gold mining on the Witwatersrand on the rivers and karst system of Gauteng and North West 
Province, South Africa," Journal of African Earth Sciences, vol. 68, no. 15, pp. 24-43, 2012.

[19] L. A. Zadeh, "Fuzzy sets," Information and Control, vol. 8, pp. 338-353, 1965.

[20] G. Onkal-Engin, I. Demir, and H. Hiz, "Assessment of urban air quality in Istanbul using fuzzy synthetic evaluation," Atmospheric Environment, vol. 38, no. 23, pp. 3809-3815, 2004.

[21] C. Q. Mi, X. D. Zhang, S. M. Li, J. Yang, D. Zhu, and Y. Yang, "Assessment of environment lodging stress for maize using fuzzy synthetic evaluation," Mathematical and Computer Modelling, vol. 54, no. 3-4, pp. 1053-1060, 2011.

[22] S. Dahiya, B. Singh, S. Gaur, V. K. Garg, and H. S. Kushwaha, "Analysis of groundwater quality using fuzzy synthetic evaluation," Journal of Hazardous Materials, vol. 147, no. 3, pp. 938946, 2007.

[23] Y. J. Guo, "New theory and method of dynamic comprehensive evaluation," Journal of Management Sciences, vol. 5, no. 2, pp. 52-57, 2002 (Chinese).

[24] Sichuan Institute of Coalfield Geological Engineering Exploration and Designing, Preliminary Geological Survey of Tongluoshan Tunnel, Sichuan Institute of Coalfield Geological Engineering Exploration and Designing, Chengdu, China, 2003.

[25] Y. Wang, W. F. Yang, M. Li, and X. Liu, "Risk assessment of floor water inrush in coal mines based on secondary fuzzy comprehensive evaluation," International Journal of Rock Mechanics \& Mining Sciences, vol. 52, pp. 50-55, 2012.

[26] Q. Zhang, X. Yang, Y. Zhang, and M. Zhong, "Risk assessment of groundwater contamination: a multilevel fuzzy comprehensive evaluation approach based on DRASTIC model," The Scientific World Journal, vol. 2013, Article ID 610390, 9 pages, 2013.

[27] H. Y. Wu, K. L. Chen, Z. H. Chen et al., "Evaluation for the ecological quality status of coastal waters in East China Sea using fuzzy integrated assessment method," Marine Pollution Bulletin, vol. 64, no. 3, pp. 546-555, 2012. 

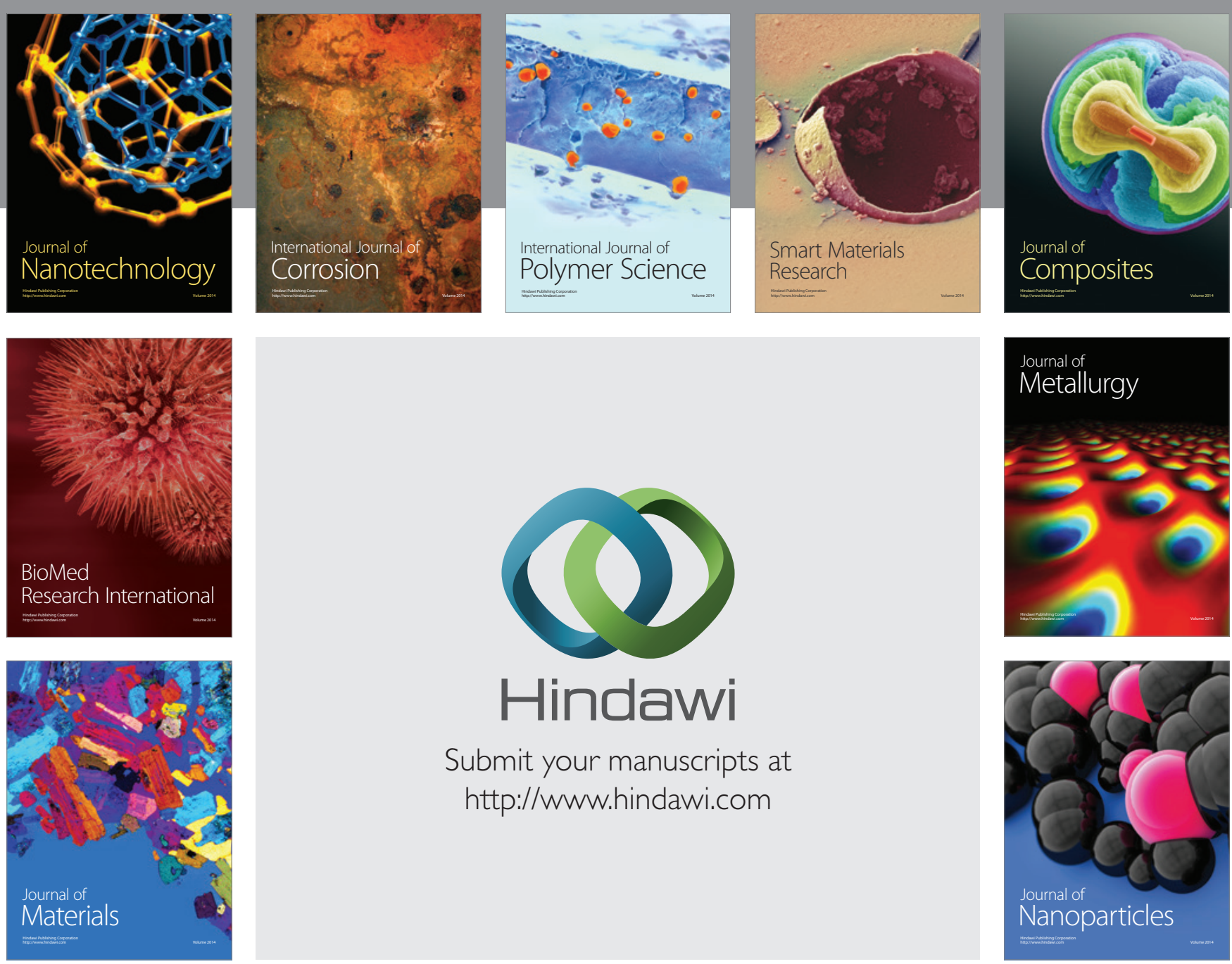

Submit your manuscripts at http://www.hindawi.com
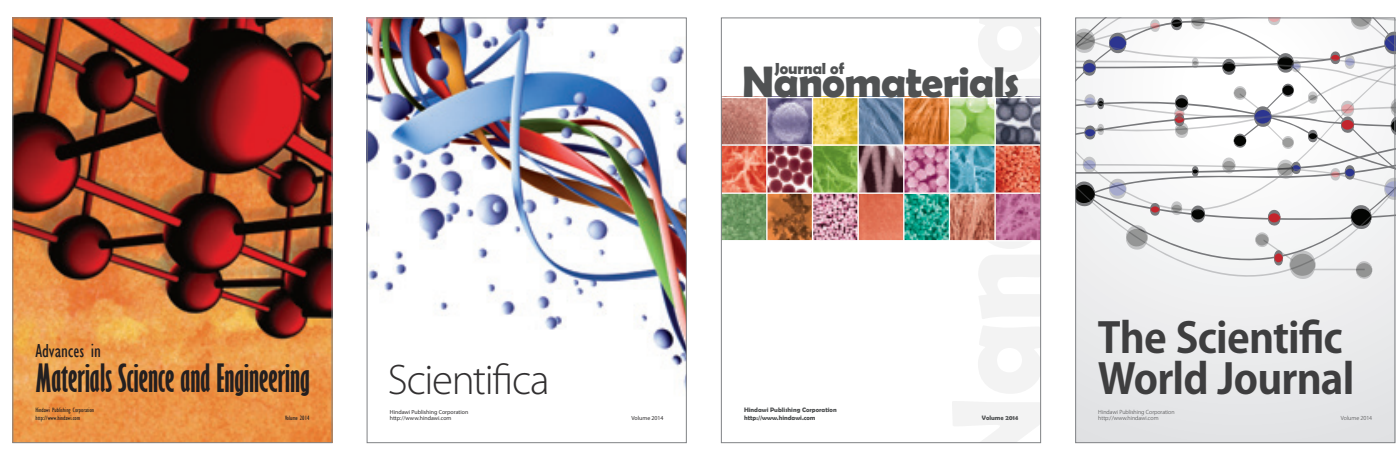

\section{The Scientific World Journal}
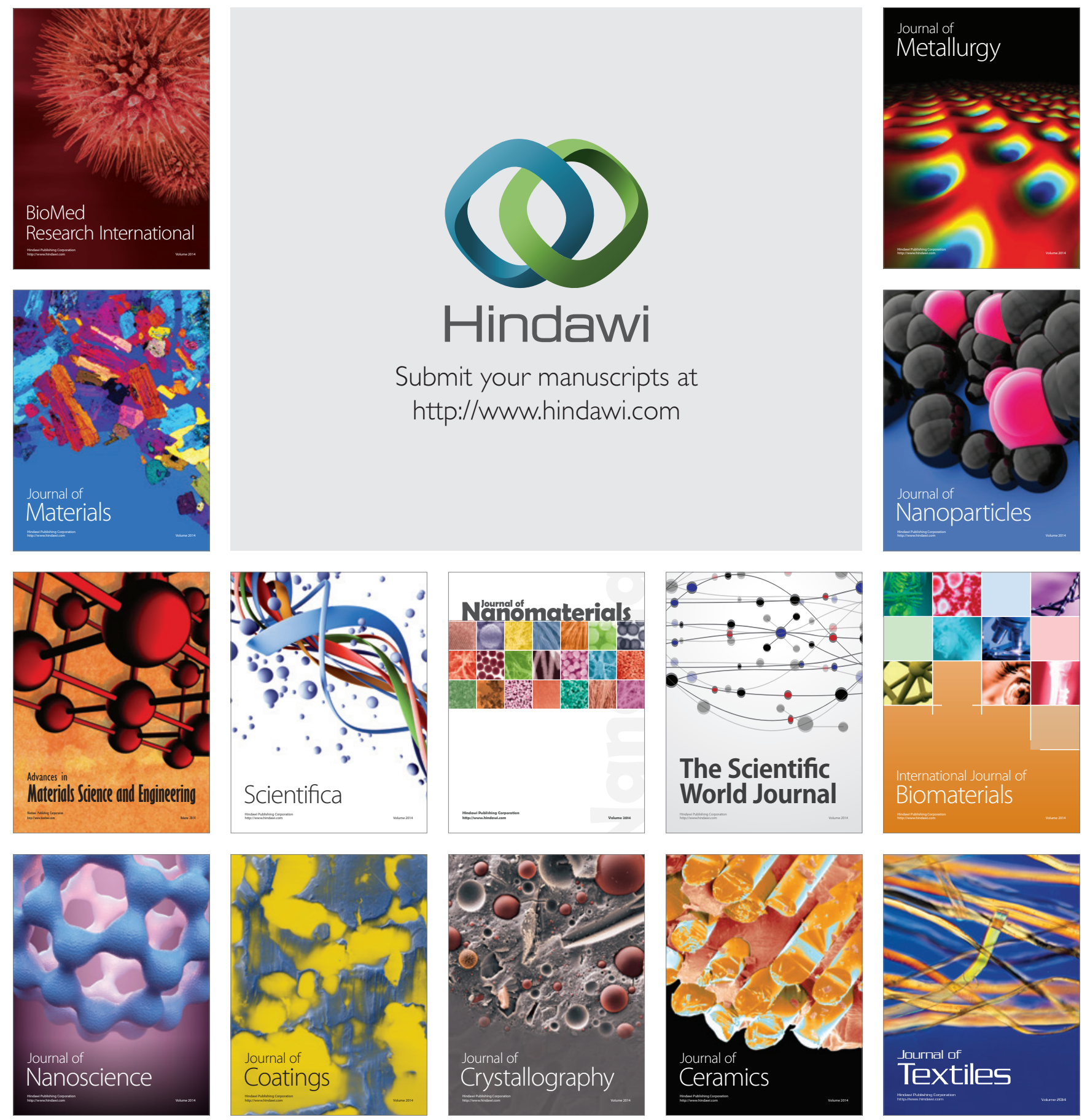